\title{
Peningkatkan Kreativitas dan Kemandirian Belajar Mahasiswa Melalui Model Pembelajaran Berbasis Proyek Pada Perkuliahan Media Pembelajaran Matematika
}

\author{
Isnaniah \\ Jurusan Pendidikan Matematika IAIN Bukittinggi \\ e-mail : $\underline{\text { Iis imam@yahoo.co.id }}$
}

\begin{abstract}
ABSTRAK. Penelitian ini bertujuan untuk mengetahui peningkatan kreativitas dan kemandirian belajar mahasiswa melalui penerapkan model pembelajaran berbasis proyek pada matakuliah media pembelajaran matematika (MPM). Jenis penelitian yang digunakan adalah Classroom Action Research, subjek penelitian adalah mahasiswa semester 3 jurusan Pendidikan Matematika yang sedang menempuh matakuliah MPM yang berjumlah 79 orang. Rancangan penelitian terdiri dari 4 tahap: perencanaan, tindakan, pengamatan dan refleksi. Instrumen yang digunakan dalam penelitian ini adalah lembar penilaian kreativitas, lembar penilaian kemandirian belajar dan tes awal. Data yang diperoleh kemudian dianalis secara deskriptif. Berdasarkan hasil analisis data diketahui bahwa kreativitas mahasiswa pada siklus 1 sebesar 60,1\% yang tergolong pada kategori sedang dan pada siklus 2 kretativitas mahasiswa sebesar $81,46 \%$ yang tergolong pada kategori tinggi. Kemandirian belajar mahasiswa pada siklus 1 sebesar 58,15\% yang tergolong pada kategori sedang dan pada siklus 2 kemandirian belajar mahasiswa sebesar 79,44\% yang tergolong pada kategori baik. Jadi, dapat disimpulkan bahwa terjadi peningkatan kreativitas dan kemandirian belajar mahasiswa melalui penerapkan model pembelajaran berbasis proyek pada matakuliah media pembelajaran matematika.
\end{abstract}

Kata Kunci : Classroom Action Research, Kemandirian Belajar, Kreativitas, Model Pembelajaran Berbasis Proyek.

\section{PENDAHULUAN}

Dalam Undang-Undang Sistem Pendidikan Nasional No. 20 pasal 3 tahun 2003 disebutkan bahwa pendidikan nasional berfungsi mengembangkan kemampuan dan membentuk watak serta perdaban bangsa yang bermartabat dalam rangka mencerdaskan kehidupan bangsa, bertujuan untuk berkembangnya potensi peserta didik agar menjadi manusia yang beriman dan bertakwa kepada Tuhan Yang Maha Esa, berakhlak mulia, sehat, berilmu, cakap, kreatif, mandiri, dan menjadi warga Negara yang demokratis serta bertanggung jawab (UU Sisdiknas, 2003). Sejalan dengan pernyataan tersebut, Badan Standar Nasional Pendidikan (BSNP) tahun 2006 merekomendasikan bahwa dalam pembelajaran perlu diciptakan suasana aktif, kritis, analisis, dan kreatif dalam pemecahan masalah (Supriadi, 1994). Matematika merupakan bidang studi yang dipelajari oleh semuasiswa dari sekolah dasar (SD), sekolah menengah (SMP/SMA) sampai di tingkat perguruan tinggi (PT) juga memiliki tujuan yang sejalan dengan pendidikan nasional dan BNSP.Berdasarkan tujuan pendidikan nasional rekomendasi BSNP tersebut perlu secara khusus dikaji tentang kreativitas dan kemandirian mahasiswa dalam menyelesaikan masalah.

Kreativitas dan kemandirian belajar mutlak harus dimiliki oleh setiap mahasiswa agar tercipta manusia yang unggul. Menurut Munandar (1990), kreativitas adalah kemampuan menemukan banyak kemungkinan jawaban terhadap suatu masalah, dimana penekanannya adalah 
pada kuantitas, ketepatgunaan, dan keragaman jawaban. Makin banyak kemungkinan jawaban yang dapat di berikan terhadap suatu masalah makin kreatiflah seseorang. Tentu saja jawaban itu harus sesuai dengan masalahnya. Jadi, tidak semata-mata banyaknya jawaban yang dapat diberikan menentukan kreativitas seseorang, tapi juga kualitas dam mutu dari jawabannya.

Kemandirian, menurut Sutari Imam Bernadib (Fatimah, 2006) meliputi perilaku mampu berinisiatif, mampu mengatasi hambatan/masalah, mempunyai rasa percaya diri dan dapat melakukan sesuatu sendiri tanpa bantuan orang lain. Mahasiswa dengan kemandirian yang tinggi, akan berusaha untuk bertanggung jawab terhadap kemajuan prestasinya, mengatur diri sendiri, memiliki inisiatif yang tinggi dan memiliki dorongan yang kuat untuk terus menerus mengukir prestasi. Mereka juga berusaha mendapatkan dan menggunakan segala fasilitas dan sumber belajar dengan sebaik-baiknya. Sikap mandiri mahasiswa dalam mengerjakan tugas harus dipupuk sedini mungkin,karena dengan sikap mandiri dapat menunjukkan inisiatif, berusaha untuk mengejar prestasi, mempunyai rasa percaya diri. Hal ini berarti dalam kemandirian terdapat sifat tanggung jawab.Tanggung jawab adalah sikap utama yang harus dimiliki oleh mahasiswa dalam belajar, mahasiswa yang bertanggung jawab biasanya tahu akan hak dan kewajibannya sebagai pelajar, memiliki kesadaran diri tinggi akan tugasnya sebagai pelajar, berusaha dengan tekun dan keras dalam memperjuangkan prestasinya dan mereka juga berani dalam mengambil tindakan atau keputusan (Rosyidah, 2010).

Memperhatikan pentingnya kreativitas dan kemandirian mahasiswa, maka kedua kemampuan ini harus dikembangkan. Salah satunya adalah dengan menerapkan model pembelajaran yang menjadikan mahasiswa sebagai pengendali pembelajaran dan bukan didominasi oleh dosen. Model pembelajaran yang didominasi oleh mahasiswa, sangat diperlukan terlebih untuk matakuliah yang mengharuskan mahasiswa kerja praktek sehingga diharapkan mahasiswa akan menemukan masalah yang ada secara mandiri dan mampu mencari pemecahan masalah serta meningkatkan kreativitas. Hanya saja, pada kenyataannya tingkat kreativitas mahasiswa saat ini masih rendah dan terlihat belum berkembang. Hal ini didasarkan pada pengalaman peneliti selama mengajar mata kuliah media pembelajaran matematika sejak tahun 2008. Produk media pembelajaran yang dihasilkan mahasiswa sebagai tugas akhir lebih cenderung mengambil tugas-tugas senior sebelumnya, hal ini menunjukkan mahasiswa belum mampu untuk mencetuskan ide sendiri, hanya sekitar $10 \%$ mahasiswa yang mampu menghasilkan produk yang original.

Selain kreativitas peneliti juga menemukan kemandirian belajar mahasiswa dalam perkuliahan media pembelajaran matematika masih kurang, hal ini terlihat dari kebiasaan mahasiswa yang hanya mau menerima dari dosen dan kurang berusaha sendiri menyelesaikan tugas yang diberikan. Ketika diberikan tugas banyak mahasiswa yang tidak bisa menyelesaikan tepat waktu dan meminta tambahan waktu, padahal tugas tersebut telah disampaikan di awal kontrak perkuliahan.

Kurangnya kreativitas dan kemandirian belajar mahasiswa diduga disebabkan karena pembelajaran yang dilaksanakan peneliti masih berpusat pada dosen sehingga mahasiswa terbiasa menerima. Pembelajaran juga kurang mengaitkan tugas yang diberikan dengan masalah nyata terkait masalah media yang ada di sekolah.

Berdasarkan pengalaman tersebut, peneliti ingin mencoba keluar dari masalah yang membelenggu selama ini. Dengan mencoba menerapkan model pembelajaran yang berpusat pada mahasiswa sehingga kreativitas dan kemandirian belajar mahasiswa meningkat. Salah satu model pembelajaran yang dapat digunakan untuk meningkatkan kreativitas dan kemandirian belajar mahasiswa yaitu Model Pembelajaran Berbasis Proyek. Model Pembelajaran Berbasis Proyek merupakan sebuah pembelajaran yang inovatif yang lebih menekankan pada belajar kontekstual melalui kegiatan-kegiatan yang kompleks. Dengan adanya kegiatan-kegiatan yang kompleks yang berkaitkan dengan kehidupan sehari-hari mahasiswa, mahasiswa lebih kreatif dan siap tanggap dalam menghadapi tantangan dalam kehidupan sehari-harinya. Menurut Thomas, dkk (Wena, 2012) kerja proyek memuat tugas-tugas yang kompleks berdasarkan kepada pertanyaan dan permasalahan yang sangat menantang, dan menuntut mahasiswa untuk merancang, memecahkan masalah, membuat keputusan, melakukan kegiatan investigasi, serta memberikan kesempatan kepada mahasiswa untuk bekerja secara mandiri. Tujuannya adalah agar mahasiswa mempunyai 
kemandirian dalam tugas yang dihadapinya.Proyek yang dimaksud adalah tugas-tugas yang kompleks atau tugas-tugas yang besar yang menantang mahasiswa untuk bekerja secara kolaboratif. Fokus pembelajaran terletak pada prinsip dan konsep inti dari suatu disiplin ilmu, melibatkan mahasiswa dalam investigasi pemecahan masalah dan kegiatan tugas-tugas bermakna yang lain, memberi kesempatan mahasiswa bekerja secara otonom dalam mengkonstruksi pengetahuan mereka sendiri dan mencapai puncaknya untuk menghasilkan produk nyata. Dengan demikian dimungkinkan mahasiswa memiliki kreativitas dan kemandirian belajar untuk bekerja dalam menghasilkan produk nyata. Hal ini sejalan dengan pendapat Clegg \& Berch (Wena, 2012) yang mengatakan bahwa melalui pembelajaran kerja proyek kreativitas dan motivasi mahasiswa/mahasiswi akan meningkat.

Beberapa hasil penelitian juga menyebutkan bahwa model pembelajaran berbasis proyek dapat meningkatkan kemandirian mahasiswa. Hasil penelitian yang dilakukan oleh Antuni (2007) memperlihatkan peningkatan kreativitas dan prestasi belajar mahasiswa melalui pembelajaran berbasis proyek pada perkuliahan Workshop Pendidikan Kimia di Universitas Negeri Yogyakarta. Penelitian yang dilakukan Kukuk dkk (Wena, 2012) pada mata kuliah proyek akhir Program DIII diperoleh kesimpulan dari hasil penelitian bahwa dengan menerapkan pembelajaran berbasis proyek dapat berdampak positif terhadap kemandirian, dan konsep.

Matakuliah media pembelajaran matematika merupakan salah satu mata kuliah keahlian berkarya (MKB) yang wajib ditempuh oleh mahasiswa jurusan pendidikan matematika dan merupakan mata kuliah prasyarat. Kompetensi yang harus dicapai setelah pembelajaran adalah mahasiswa mampu merancang, membuat, menggunakan media pembelajaran matematika (alat peraga matematik)serta dapat mengaplikasikan dalam kehidupan bermasyarakat. Alat peraga yang dibuat haruslah dapat menumbuhkan konsep abstak dan menimbulkan sikap belajar aktif, baik secara individu ataupun berkelompok (Suherman, 2001). Model Pembelajaran berbasis proyek memungkinkan diterapkan untuk matakuliah media pembelajaran matematika yang memerlukan kerja praktek. Dengan Model Pembelajaran berbasis proyek diharapkan dapat meningkatkan kreativitas dan kemandirian belajar mahasiswa.

Berdasarkan uraian yang telah dipaparkan, maka rumusan masalah pada penelitian ini adalah :

1. Apakah dengan penerapan model pembelajaran berbasis proyek dapat meningkatkan kreatvitas mahasiswa pada perkuliahan media pembelajaran matematika pada jurusanPendidikan Matematika Fakultas Tarbiyah dan Ilmu Keguruan (FTIK) IAIN Bukittinggi?

2. Apakah dengan penerapan model pembelajaran berbasis proyek dapat meningkatkan kemandirian belajar mahasiswa pada perkuliahan media pembelajaran matematika pada jurusanPendidikan Matematika fakultas Tarbiyah dan Ilmu Keguruan (FTIK) IAIN Bukittinggi?

\section{METODE PENELITIAN}

Penelitian ini menggunakan metode Penelitian Tindakan Kelas (PTK) atau dikenal dengan Classroom Action Research model Kammis. Menurut Kammis (Wijaya dan Syahrum, 2013), penelitian tindakan kelas adalah bentuk penelitian refleksi diri yang dilakukan oleh para partisipan dalam situasi-situasi sosial (termasuk pendidikan) untuk memperbaiki praktik yang dilakukan sendiri. Penelitian ini bermaksud mengungkapkan suatu upaya dalam meningkatkan kreativitas dan kemandirian belajar mahasiswa melalui model pembelajaran berbasis proyek pada mata kuliah media pembelajaran matematika.

Subjek penelitian adalah mahasiswa jurusan pendidikan matematika yang sedang menempuh mata kuliah media pembelajaran matematika semester 3 Tahun Akademik 2016/2017 yaitu sebanyak 79 subjek yang terdistribusi dalam 3 kelas. Dari setiap kelas dibagi menjadi 4 kelompok, sehingga sabjek terbagi menjadi 12 kelompok. Setiap kelompok terdiri atas mahasiswa dengan kemampuan yang heterogen (kemampuan tinggi, sedang dan rendah). Objek penelitian 
meliputi kreativitas dan kemandirian belajar mahasiswa pada mata kuliah media pembelajaran matematika. Penelitian dilakukan sebanyak 2 (dua) siklus. Dalam setiap siklus setiap kelompok secara mandiri membuat media pembelajaran matematika sesuai dengan rancangannya, mempresentasikan serta memberikan tanggapan/masukan terhadap media kelompok lain. Adapun tahapan-tahapan yang dilakukan pada setiap siklus adalah sebagai berikut:

1. Perencanaan

Pada tahap ini, dimulai dari penyampaian rencana pembelajaran, pemberian pretes, pemberian materi tentang konsep dasar media pembelajaran matematika, orientasi pada media pembelajaran matematika yang sudah ada sebagai dasar dalam mengembangkan dan mengukur kreativitas mahasiswa.

2. Tindakan

Pada tahap ini, dimulai dari analisis mahasiswa tentang keberadaan media pembelajaran matematika oleh mahasiswa di sekolah. Kemudian mahasiswa mengumpulkan informasi dan kajian literatur sehingga mampu merumuskan straregi pemecahan masalah. Langkah selanjutnya mahasiswa secara individu dalam kelompok menyelesaikan permasalahan yang ada dengan membuat model/rancangan media pembelajaran matematika yang akan dibuat dan melakukan analisi konstruksi dan kalkulasi bahan serta prosedurpembuatannya, selanjutnya mahasiswa mendiskusikan hasil penyelesaian masalah secara individu kedalam kelompoknya. Dari hasil diskusi kelompok mahasiswa memperoleh keputusan dalam menyelesaikan masalah yang ada.Selamjutnya, mahasiswa mulai bekerja membuat produk media pembelajaran matematika sebagaimana yang telah didesain sebelumnya. Setelah media menjadi produk nyata, mahasiswa melakukan uji coba alat dalam kelompok masing-masing dan di akhiri dengan presentasi di kelas dan disertai penyusunan makalah tentang media yang dibuatnya.

3. Pengamatan

Pada tahap ini, dilakukan pemantauan terhadap kegiatan yang dilakukan. Pengamatan dilakukan terhadap proses tindakan, efek tindakan dan terhadap hasil tindakan yang dilakukan serta sejauh mana tindakan yang dilakukan untuk membantu pencapaian tujuan yang telah di rencanakan.

4. Refleksi

Refleksi dilakukan untuk melakukan penilaian terhadap proses yang terjadi dan segala hal yang berkaitan dengan tindakan yang dilakukan. Refleksi dilakukan dengan cara kolaboratif yaitu adanya diskusi tentang berbagai masalah yang muncul di kelas sehingga ditemukan strategi pemecahan masalah untuk perbaikan tindakan yang harus dilakukan bagi siklus berikutnya.

Sesuai dengan tujuan penelitian, ada beberapa instrumen yang digunakan dalam penelitian ini yaitu lembar penilaian kreativitas, lembar penilaian kemandirian dan tes awal. Lembar penilaian kreativitas digunakan untuk menilai kreativitas mahasiswa dalam merancang proyek yaitu media pembelajaran matematika. Lembar penilaian disusun berdasarkan indikator kreativitas, yaitu kelancara, keluwesan, keaslian dan elaborasi. Lembar penilaian kemandirian merancangan media pembelajaran matematika. Instrumen ini digunakan untuk menilai kemandirian mahasiswa dalam merancang proyek yaitu media pembelajaran matematika. Lembar penilaian disusun berdasarkan berdasarkan indikator kemandirian, yaitu : percaya diri, disiplin, inisiatif dan tanggung jawab. Instrumen tambahan untuk melengkapi data yaitu uji awal pengetahuan mahasiswa mengenai media pembelajaran matematika untuk dibandingkan dengan hasil refleksi 1 sehingga dapat menentukan apakah pengetahuan mahasiswa mempengaruhi keberhasilan tindakan.

Pengumpulan data dilakukan sejak awal hingga akhir penelitian melalui angket dan pengamatan. Penskoran angket dilakukan reting scale, dengan kriteria sebagai berikut: 
Tabel 1. Kriteria Penilaian Kreativitas dan Kemandirian Mahasiswa

\begin{tabular}{cc}
\hline Skala & Kriteria \\
\hline 0 & Indikator tidak muncul \\
\hline 1 & Kurang baik \\
\hline 2 & Cukup baik \\
\hline 3 & Baik \\
\hline 4 & Sangat baik \\
\hline
\end{tabular}

Data yang telah diperoleh dari hasil pengamatan dan angket dianalisis secara kualitatif deskriptif. Skor yang diperoleh dari angket dihitung persentasenya, dengan kategori sebagai berikut (Riduwan, 2003) :

Tabel 2.Kategori Kemampuan Berpikir Kreatif Mahasiswa

\begin{tabular}{ccc}
\hline No. & Kemampuan Berpikir Kreatif & Predikat \\
\hline 1 & $80 \%-100 \%$ & Tinggi \\
\hline 2 & $60 \%-79 \%$ & Sedang \\
\hline 3 & $<60 \%$ & Kurang \\
\hline
\end{tabular}

Tabel 3.Kategori Kemandirian Belajar Mahasiswa

\begin{tabular}{ccc}
\hline No. & Kemandirian Belajar & Predikat \\
\hline 1 & $81 \%-100 \%$ & Baik Sekali \\
\hline 2 & $61 \%-80 \%$ & Baik \\
\hline 3 & $41 \%-60 \%$ & Cukup \\
\hline 4 & $21 \%-40 \%$ & Rendah \\
\hline 5 & $0 \%-20 \%$ & Sangat Rendah \\
\hline
\end{tabular}

\section{HASIL PENELITIAN DAN PEMBAHASAN}

\section{A. Penelitian Siklus 1}

\section{Tahap Perencanaan}

Tahap perencanaan dimulai pada pertemuan pertama yang diawali dengan penyampaian rencana pembelajaran yang akan dilaksanakan. Kemudian dipertemuan ke dua, pemberian pretes untuk mengungkap kemampuan awal mahasiswa tentang media pembelajaran matematika. Pre tes diikuti oleh 29 orang dari kelas 3A, 25 orang dari kelas 3B dan 25 orang dari kelas 3C, sehingga total subjek yang mengikuti pretes adalah 79 orang. Rata-rata hasil pretes setiap kelas terlihat pada tabel berikut :

Table. 4. Rata-Rata Nilai Pretes Media Pembelajaran Matematika

\begin{tabular}{cc}
\hline Kelas & Rata-Rata \\
\hline A & 16,38 \\
\hline B & 11,06 \\
\hline C & 16,78 \\
\hline Rata-rata & 14,74 \\
\hline
\end{tabular}

Dari tabel di atas rata-rata kempuan awal mahasiswa dalam mata kuliah media pembelajaran matematika sebesar 14,74. Hal ini menunjukan kempuan awal mahasiswa dalam mata kuliah media pembelajaran matematika masih rendah.

Pada pertemuan ketiga, mahasiswa diorientasikan pada media pembelajaran matematika yang sudah ada, sebagai dasar dalam mengembangkan dan mengukur kreativitas mahasiswa. Pada saat pemberian orientasi juga dilakukan tanya jawab tentang media pembelajaran yang sudah ada dan hasilnya sejalan dengan hasil pretes. 


\section{b. Tahap Tindakan}

Pada tahap ini, dimulai dari pertemuan ke empat sampai pertemuan ke tujuh. pertemuan ke 4 dilaksanakan di minggu yang sama dengan pertemuan ke tiga di hari yang berbeda. Dimulai dari analisis mahasiswa tentang permasalah media pembelajaran yang dihadapi oleh guru-guru matematika di sekolah dasar (hal ini sesuai dengan kurikulum di jurusan pendidikan matematika untuk mata kuliah media pembelajaran matematika, mahasiswa diharapkan dapat merancang, membuat, menggunakan serta mengaplikasikan media pembelajaran matematika dari tingkat dasar sampai lanjutan sebagai bekal mahasiswa menjadi calon guru nantinya). Kemudian mahasiswa mengumpulkan informasi dan kajian literatur sehingga mampu merumuskan straregi pemecahan masalah. Langkah selanjutnya mahasiswa secara individu dalam kelompok menyelesaikan permasalahan yang ada dengan membuat model/rancangan media pembelajaran matematika yang akan dibuat dan melakukan analisi konstruksi dan kalkulasi bahan serta prosedurpembuatannya, selanjutnya mahasiswa mendiskusikan hasil penyelesaian masalah secara individu kedalam kelompoknya. Dari hasil diskusi kelompok mahasiswa memperoleh keputusan dalam menyelesaikan masalah yang ada. Selamjutnya, mahasiswa mulai bekerja membuat produkmedia pembelajaran matematika sebagaimana yang telah didesain sebelumnya. Setelah media menjadi produk nyata, mahasiswa melakukan uji coba alat dalam kelompok masing-masing dan di akhiri dengan presentasi di kelas dan disertai penyusunan makalah tentang media yang dibuatnya.

\section{c. Tahap Pengamatan}

Pada tahap ini, dilakukan pemantauan terhadap kegiatan yang dilakukan. Pengamatan dilakukan terhadap proses tindakan, efek tindakan dan terhadap hasil tindakan yang dilakukan serta sejauh mana tindakan yang dilakukan untuk membantu pencapaian tujuan yang telah di rencanakan mulai dari pertemuan ke empat sampai pertemuan ke 7. Pengamatan dilakukan di 12 kelompok. Setiap kelompok diwakili oleh mahasiswa dengan kemampuan tinggi, sedang dan rendah. Jadi total subjek yang diamati aadalah 36 subjek disetiap pertemuannya.

Pengamatan yang dilakukan pada pertemuan 4 terkait dengan kemandirian belajar mahasiswa di sekolah dalam melakukan identifikasi masalah media pembelajaran matematika. Pada pertemuan ke 5 sampai 7 dilakukan pemantauan terhadap proses pembelajaran dan dilakukan penilaian tentang kreativitas dan kemandirian belajar mahasiswa di dalam kelas.Kreativitas yang diamati terdiri dari 4 indikator yaitu kelancaran, keaslian, keluwesan dan elaborasi. Rata-rata kreativitas pada pertemuan 5 sebesar 55,6\% yang tergolong pada kategori rendah, pada pertemuan ke 6 sebesar 55,38\% yang tergolong pada kategori rendah, pada pertemuan 7 sebesar 69,09\% yang tergolong pada kategori sedang, Jadi dari rata-rata pertemuan 5-6 diperoleh kreativitas belajar mahasiswa pada siklus 1 sebesar 60,01\% yang tergolong pada kategori sedang.

Kemandirian belajar terdiri dari 5 indikator yaitu percaya diri, disiplin, inisiatif, tanggung jawab, dan motivasi. Dari hasil analisis data diperoleh rata-rata Kemandirian belajar mahasiswa di kelas pada pertemuan 5 sebesar 52,62\% yang tergolong pada kategori rendah, pada pertemuan ke 6 sebesar 58,54\% yang tergolong pada kategori rendah, pada pertemuan 7 sebesar 61,67\% yang tergolong pada kategori sedang, Jadi dari rata-rata pertemuan 5-6 diperoleh kemandirian belajar mahasiswa di kelas pada siklus 1 sebesar 57,61\% yang tergolong pada kategori sedang. Data persentase kemandirian mahasiwa dalam mengidentifikasi masalah media pembelajaran di sekolah sebesar 58,69\% dan kemandirian belajar mahasiswa di kelas sebesar 51,61\% diperoleh kemandirian belajar mahasiswa pada siklus 1 sebesar 58,15\% yang tergolong pada kategori sedang.

\section{d. Refleksi}

Refleksi dilakukan untuk melakukan penilaian terhadap proses yang terjadi dengan segala hal yang berkaitan dengan tindakan yang dilakukan. Refleksi dilaksanakan secara kolaboratif yaitu adanya diskusi kelas dengan mahasiswa untuk mengungkap permasalahan yang ada serta strategi 
pemecahan untuk perbaikan tindakan siklus berikutnya. Diskusi dengan mahasiswa dilaksanakan dengan menambah jam kuliah setelah semua kelompok mempersentasikan media pembelajaran yang dibuat. Refleksi juga dilakukan oleh dosen lain yang berperan sebagai observer dalam penelitian ini yaitu dosen media pembelajaran yang mengajar di kelas lain yang bernama M.Imamuddin, M.Pd. sehingga diharapkan hasil refleksi benar-benar objektif. Berikut ini kesimpulan yang diperoleh dari refleksi siklus 1 :

a) Pengetahuan awal mahasiswa tentang media pembelajaran matematika masih rendah

b) Keberanian mahasiswa dalam bertindak mengidentifikasi masalah materi pelajaran matematika di sekolah masih kurang dan respon yang diberikan mahasiswa terhadap penjelasan guru masih belum sesuai sehingga masalah yang diidentifikasi tidak sepenuhnya terungkap.

c) Adanya dominasi mahasiswa yang kemampuan tinggi dan yang pandai berbicara sehingga potensi mahasiswa yang lainnya tidak begitu terlihat saat di sekolah.

d) Mahasiswa dalam menyelesaikan masalah berdasarkan hasil observasi dan wawancara masih belum sepenuhnya dapat mengungkap ide-idenya karena masih tergantung dengan teman kelompoknya.

e) Mahasiswa dalam mengembangkan media pembelajaran masih kurang sesuai dengan konsepkonsep dalam matematika

f) Masih banyak mahasiswa yang belum menggunakan literatur/reverensi

g) Bahan-bahan yang telah ditetapkan untuk membuat media pembelajaran matematika berdasarkan hasil rancangan teryata tidak tersedia di toko-toko.

h) Mahasiswa masih kurang memperhatikan syarat-syarat sebuah media pembelajaran matematika.

i) Masih ada beberapa kelompok yang kurang memperhatikan temannya saat presentasi karena sibuk dengan media pembelajaran sendiri.

j) Kurangnya kerjasama dalam kelompok dan miskomunikasi sehingga untuk media di pertemuan awal tidak selesai.

\section{B. Penelitian Siklus 2}

1. Tahap Perencanaan

Siklus ke 2 dimulai pada pertemuan ke delapan berdasarkan refleksi siklus 1, pertemuan ke delapan dilaksanakan di minggu yang sama dengan pertemuan yang ke tujuh di hari yang berbeda, ada beberapa perbaikan yang dilakukan. Yang pertama adalah pemantapan tentang materi media pembelajaran matematika terutama tentangsyarat-syarat sebuah media pembelajaran matematika (MPM) dan mahasiswa diwajibkan membawa reverensi tentang buku pelajaran sekolah dan reverensi MPM yang bertujuan agar mahasiswa dalam marancang dan menggunakan media tidak menyalahi konsep dalam matematika. Yang kedua, megatur jarak/posisi duduk dalam kelompok hal ini bertujuan untuk meminimalisir ketergantungan antar sesama kelompok dalam melahirkan ide-ide untuk menyelesaikan masalah dan agar mahasiswa juga lebih fokus. Yang ke tiga, dalam mengidentifikasi masalah real/nyata di sekolah, mahasiswa dipasangkan sesuai dengan kemampuannya sehingga tidak ada yang mendominasi dan menghimbau kepada mahasiswa agar tetap memperhatikan kedisiplinan dan menunjukan sikap keberanian dalam bertindak mengidentifikasi masalah. 


\section{Tahap Tindakan}

Seperti pada siklus 1, pelaksanaan siklus 2 pada tahap tindakan adalah dimulai dari analisis mahasiswa tentang permasalah media pembelajaran yang dihadapi oleh guru-guru matematika di sekolah menengah pertama. Kemudian mahasiswa mengumpulkan informasi dan kajian literatur sehingga mampu merumuskan straregi pemecahan masalah. Langkah selanjutnya mahasiswa secara individu dalam kelompok menyelesaikan permasalahan yang ada dengan membuat model/rancangan media pembelajaran matematika yang akan dibuat dan melakukan analisi konstruksi dan kalkulasi bahan serta prosedurpembuatannya, selanjutnya mahasiswa mendiskusikan hasil penyelesaian masalah secara individu kedalam kelompoknya. Dari hasil diskusi kelompok mahasiswa memperoleh keputusan dalam menyelesaikan masalah yang ada.Selanjutnya, mahasiswa mulai bekerja membuat produk media pembelajaran matematika sebagaimana yang telah didesain sebelumnya. Setelah media menjadi produk nyata, mahasiswa melakukan uji coba alat dalam kelompok masing-masing dan di akhiri dengan presentasi di kelas. Setiap kelompok harus benar-benar memperhatikan presentasi kelompok yang lainnya agar dapat memberikan masukan demi perbaikan produk dan yang tampil presentasi dipergilirkan sehinnga setiap anggota kelompok berperan aktif.

\section{Tahap Pengamatan}

Sama dengan siklus 1, Pada tahap inidilakukan pemantauan terhadap kegiatan yang dilakukan. Pengamatan dilakukan terhadap proses tindakan, efek tindakan dan terhadap hasil tindakan yang dilakukan serta sejauh mana tindakan yang dilakukan untuk membantu pencapaian tujuan yang telah di rencanakan mulai dari pertemuan ke 8 sampai pertemuan ke 11. Pengamatan dilakukan di 12 kelompok. Pengamatan yang dilakukan pada pertemuan 8 terkait dengan kemandirian belajar mahasiswa di sekolah menengah pertama (SMP) dalam melakukan identifikasi masalah media pembelajaran matematika. Pada prtemuan ke 8 dilakukan pemantauan terhadap kemandirian belajar mahasiswa dalam mengidentifikasi masalah media pembelajaran matematika di sekolah. Setelah di lakukan perhitungan diperoleh rata-ratakan kemandirian belajar mahasiswa dalam mengidentifikasi masalah di sekolah sebesar 85,94\% dan tergolong baik sekali.

Pada pertemuan ke 9 sampai 11 dilakukan pemantauan terhadap proses pembelajaran dan dilakukan penilaian tentang kreativitas dan kemandirian belajar mahasiswa di dalam kelas. Pada sikus 2 cara penyajian datanya dilakukan secara umum. Kreativitas belajar mahasiswa pada siklus 2 sebesar 80,41\% yang tergolong pada kategori tinggi. Dan kemandirian belajar mahasiswa di kelas sebesar 71,91\% yang tergolong baik. Kemandirian belajar mahasiswa diperoleh dari ratarata kemandirian belajar mahasiswa dalam mengidentifikasi masalah media di sekolah yaitu 85,94\% dan Kemandirian belajar mahasiswa di kelas sebesar 71,91 \% . Jadi besar presentase Kemandirian belajar mahasiswa adalah $78,95 \%$ yang tergolong baik.

\section{Refleksi}

Pada akhir siklus 2 juga akan dilakukan refleksi, hasil refleksi sementara berdasarkan hasil pengamatan dan dosen kolaboratif merekomendasikan penekanan pada masalah pemahaman konsep matematika tidak hanya pemahaman tentang media pembelajaran matematika karena bagaimanapun bagusnya media yang telah dibuat tetepi jika informasi yang akan disampaikan itu belum betul maka juga akan berdampak kepada pemahaman orang/siswa yang akan menerima informasi. Selain itu, hal yang dapat mempengaruhi kemampuan mahasiswa dalam merancang, membuat dan menggunakan media pembelajaran matematika untuk tingkat sekolah menengah pertama adalah kemampuan individu yang bergabung dalam satu kelompok dengan kelompok lainnya kurang seimbang meskipun secara akademis seimbang. 


\section{PENUTUP}

A. Kesimpulan

Berdasarkan hasil penelitian dan pembahasan dapat disimpulkan bahwa:

1. Dengan menerapkan model pembelajaran berbasis proyek pada mata kuliah media pembelajaran matematika dapat meningkatkan kreativitas mahasiswa. Pada siklus 1 diperoleh kreativitas mahasiswa sebesar $60,1 \%$ yang tergolong pada kategori sedang dan pada siklus 2 kreativitas mahasiswa sebesar $80,41 \%$ yang tergolong pada kategori tinggi

2. Dengan menerapkan model pembelajaran berbasis proyek pada mata kuliah media pembelajaran matematika dapat meningkatkan kemandirian belajar mahasiswa. Pada siklus 1 diperoleh kemandirian belajar mahasiswa sebesar 58,15\% yang tergolong pada kategori sedang dan pada siklus 2 kemandirian belajar mahasiswa sebesar 78,93\% yang tergolong pada kategori baik.

B. Saran

1. Mata kuliah media pembelajaran matematika sebaiknya tidak disajikan di semester 3 disebabkan karena konsep matematika mahasiswa belum terlalu luas.

2. Jika ingin penerapan model pembelajaran berbasis proyek maka sebaiknya 3 SKS jam matakuliah mata kuliah media pembelajaran matematika dibagi 1 SKS untuk merancang dan 2 SKS untuk membuat dan melakukan uji coba produk dalam kelompok dan antara kelompok.

3. Mata Kuliah media pembelajaran matematika memerlukan biaya yang besar oleh karena itu sebaiknya alat dan bahan yang dibutuhkan untuk belajar merancang, membuat dan menggunakan alat difasilitasi oleh pihak fakultas.

4. Ruangan labor pembelajaran matematika sebaiknya tidak digunakan untuk perkuliahan mata kuliah yang lain untuk menjaga media yang telah dihasilkan dan mahasiswa ingin belajar tentang produk baru tidak terbatas oleh waktu.

5. Sebaiknya jurusan pendidikan matematika tidak hanya memiliki labor pembelajaran matematika saja tetapi juga memiliki secara khusus labor komputasi yang nantinya dapat digunakan juga untuk mendesain media berbasis komputer.

\section{DAFTAR PUSTAKA}

Antuni,W. 2007. Penerapan Pembelajaran Berbasis Proyek pada Perkuliahan Workshop Pendidikan Kimia untuk. Menin gkatkan Kemandirian dan Prestasi Belajar Mahasiswa. Makalah FMIPA Univeritas Yogyakarta.

Fatimah, E. 2006. Psikologi Perkembangan. Bandung : CV Pustaka Setia.

Riduwan. 2013.Skala Pengukuran Variabel-V ariabel Penelitian. Bandung : Alfabeta.

Rosyidah. 2010. Hubungan antara Kemandirian Belajar dengan Hasil Belajar Matematika Pada Siswa MTs N Parung-Bogor. Jakarta: UIN Syarif Hidayatullah.

Suherman, E. 2001. Strategi Pembelajaran Matematika Kontemporer. Bandung: JICA Universitas Pendidikan Indonesia.

Supriadi, D. 1994. Kreativitas Kebudayaan dan Perkembangan IPTEK. Bandung: Alfabeta.

Undang-undang Sistem Pendidikan Nasional 2003.

Wena, M. 2012. Strategi Pembelajaran Inovatif Kontenporer, Suatu Tinjauan Konseptual Operasional. Jakarta: Bumi Aksara

Wijaya, C dan Syahrum. 2013.Penelitian Tindakan Kelas. Medan: IKPI. 